\title{
Analysis of Modern Social Technology to Support Publishing Industry
}

\author{
Dian Gita Utami ${ }^{1 *}$, Adrianza Putra ${ }^{2}$, Mahir Pradana ${ }^{3}$
}

${ }^{1}$ School of Business and Management, Bandung Institute of Technology, Indonesia

${ }^{2}$ Magister of Management, Hasanuddin University, Indonesia

${ }^{3}$ School of Communication and Business, Telkom University, Indonesia

\section{*Corresponding Author}

Dian Gita Utami

\section{Article History}

Received: 13.01 .2020

Accepted: 20.01 .2020

Published: 23.01.2020

\begin{abstract}
Social media platforms such as Facebook and Twitter have grown very rapidly in the last decade. We can no longer see them merely as leisure activities, since they have proved to have played important role in driving large groups of people. The political revolutions in several North African countries are the proof. The purpose of this paper is to show whether various social media platforms can also be useful in community marketing, considering the great impacts they have in modern society. In addition, we also would like to focus on other platforms other than the popular ones (Facebook and Twitter) which can also be used in community marketing.
\end{abstract}

Keywords: Digital business, internet, e-business, social media marketing.

\section{INTRODUCTION}

In the times of rapid digital technology development, traditional textbooks are having severe competitions against digital books. However, Willingham [1] argues that technology is not always a bad thing against traditional books, for two reasons that the great success of e-books as simply the porting over of traditional books into another format. However, the market of traditional books still cannot be neglected since they have different content, different structure, and they are used for different purposes. Electronic textbooks also stand a much higher chance of success if publishers will exploit the rich research literature on multimedia learning, but most are not doing so.

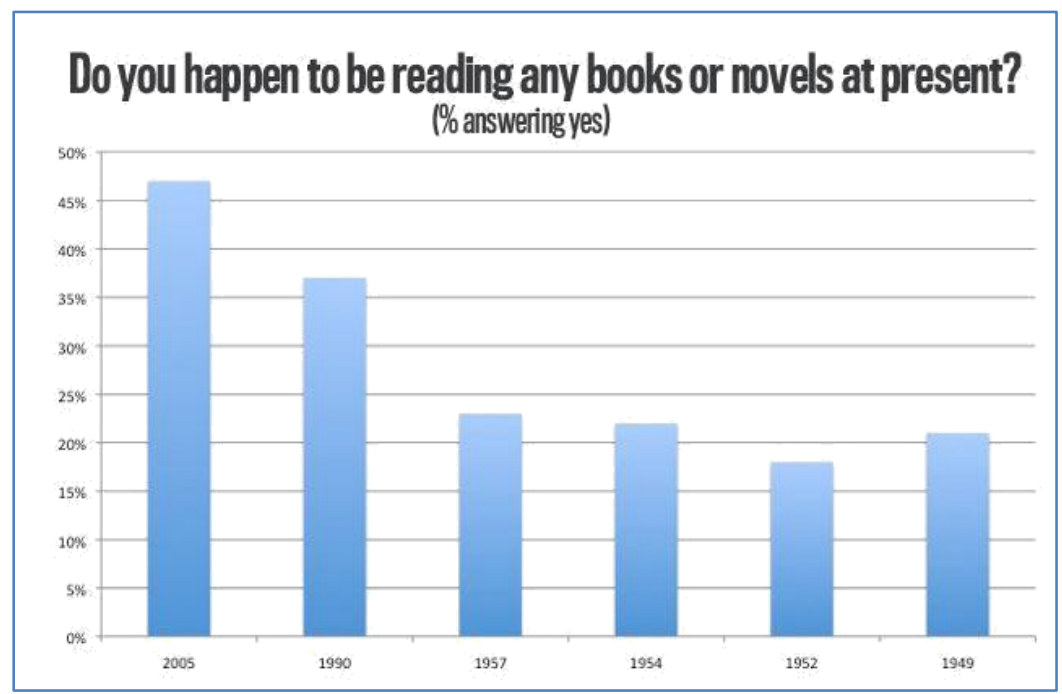

Fig-1: Percentage of reading in the USA over the years (www.danielwillingham.com)

Copyright @ 2020: This is an open-access article distributed under the terms of the Creative Commons Attribution license which permits unrestricted use, distribution, and reproduction in any medium for non commercial use (NonCommercial, or CC-BY-NC) provided the original author and source are credited. 
The development of social media also brings people with the same interest together. Hence, nowadays we can find a lot of online reading communities which exist on Facebook, Twitter, goodreads.com, Amazon Book Club, or Red Room Writer Society. Therefore, book companies need to engage these communities into their marketing activities. According to Bryan [2], community marketing is a strategy to engage an audience in an active, non-intrusive prospect and customer conversation which focuses on the needs of existing customers'.

In this paper, we are going to focus on the biggest social media platforms, which are the most preferable to be used in promoting books to the readers. The platforms are Facebook, Youtube and Twitter.

\section{LITERATURE REVIEW}

Nowadays, the role of digital business has been growing in significance [3]. According to Kaplan and Haenlein [4], social media is a group of Internet-based applications that build on the ideological and technological foundations of Web 2.0 which allows the creation and exchange of user-generated content. Corporate decision makers try to identify ways in which firms can make profitable use of various social media applications, such as YouTube, Facebook, Instagram, Path and Twitter. Social media is preferred as a powerful marketing tools because it can reach wide range of people and enable the companies to directly interact with their consumers, next to a fundamental reason that social media is less costly than any traditional marketing activities [5]. Furthermore, according to Hoffmann and Fodor [6], social media efforts are developed under the $4 \mathrm{C}^{\prime}$ s p principles: connection, creation, consumption and control. These principles are the consumer's motivations that lead to the companies' return on investments (ROI), which is measured by active participations such as a tweet or retweet, comments, review, share, or recommendations. The consumer's reaction and participations might be out of the companies' control, but the frameworks and strategies of using social media platforms are fully under the companies' supervision.

One example among the industries that directly optimizes the use of social media marketing is publishing industry. Social media industry can be used in establishing trends, reporting news and opinion, and generating buzz. Through social media, publishers can monitor trends, and listen'conversations online about their products [7]. Several publishing companies, most notably Penguin Books, Harper Collins, or Simon and Schuster, already exist on Facebook, Twitter, as well as company blogs and mobile phone social media platforms such as Instagram. As the technology of mobile phones also moves rapidly, they have now worked together with online stores such as Apple Store (iBooks).

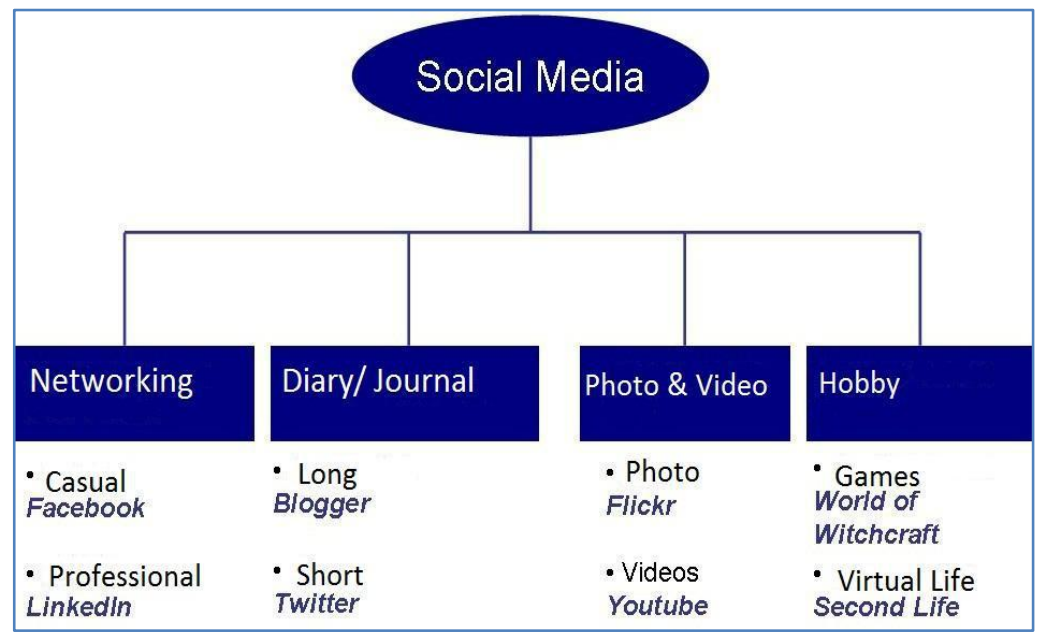

Fig-2: Different Types of of Social Media Platforms [15]

Boyd and Ellison [8] defined social network platforms as web-based social media applications through the creation and maintenance of relationships (networking). It can be supported by allowing users to create a profile and remain in contact with their network. Kaplan and Haenlein [9] created a classification scheme in their Business Horizons article, with six different types of social media: collaborative projects (for example, Wikipedia), blogs and microblogs (for example, Twitter), content communities (for example, YouTube and Daily Motion), social networking sites (for example, Facebook), virtual game worlds (e.g., World of Warcraft), and virtual social worlds (e.g. Second Life).

This study will focus on several popular social media platforms, which are YouTube, Facebook and Twitter. The platforms are used by the company for their business activities. However, the company still has no specific measurements regarding the online feedback they get from the consumers. We still have no idea how many or what types of online participation are considered a good or bad remark toward the company and how the feedbacks are going to be 
used to improve the company's business performance in the future. This study will also try to fill the gap on those matters.

\section{DISCUSSION}

\section{Strength and Limitations of Social Media Marketing}

three levels:

According to Homburg and Krohmer [10], the success of marketing of products and services can be viewed at

1. From external (outside the company) point of view:

All marketing-related activities such as the extraction of information about the market, the product design and the supply, pricing, distribution, and communication products and services.

2. From the internal (the corporate) point of view:

The implementation of the above market-related activities is well-managed and strategically put, so that the marketing can be organized very efficiently and effectively.

3. The third view combines the above two considerations and aimed at the optimal design of the consumer relationships.

In the context of social media, community marketing is the modern implementation for Word of Mouth Marketing (WOM). The WOM concept is based on the flow of information that consumer gives to their friends and acquaintances in terms of product and service reviews to give much greater confidence than marketing messages [11]. The aim of the WOM marketing is, therefore, to promote communication between satisfied consumers and their environment. According to Hennig-Thurau et al. [12], the rapid development of web-based communication, has created a new kind of WOM, the so-called electronic Word of Mouth (eWOM). The act of liking, commenting and sharing of corporate Facebook or Youtube, or re-tweeting a post on corporate Twitter is part of the eWOM.

From internal marketing perspective, there is still often great skepticism about social media. The consequence of having active social media activities is that the flow of information might be overwhelmed. As already mentioned above, social media users are globally connected and can anytime get into the eWOM process 24 hours a day, seven days a week. Therefore, there will be demand to respond to consumers _ inquiries or requests on time. Without the support of the management in the form of adequate resources for social media, failures are unavoidable.

Another major risk is the chance of exposing bad feedback from the consumers. Social media offers consumers a great platform to communicate their dissatisfaction with certain products and services, to the public (for example, through blogs) or to existing contacts (through a social network such as Facebook). This shift of power in favor of the consumer therefore bears risks for companies, as dissatisfied consumers can reveal their frustrations to a worldwide audience. Consequently, the intended eWOM activities can in the end become negative eWOM, as not everything posted in the social media can be controlled by the corporate [13].

Table-1: External and Internal Point of View

\begin{tabular}{|c|c|c|}
\hline & Chances & Risks \\
\hline $\begin{array}{l}\text { External Point } \\
\text { of View }\end{array}$ & $\begin{array}{l}\text { + Market } \\
\text { Information(Monitoring) } \\
\text { + Cheap and Fast Market } \\
\text { Research } \\
\text { + WOM Marketing } \\
\text { + Possibility to build relations } \\
\text { With other media. }\end{array}$ & \\
\hline $\begin{array}{l}\text { Internal Point } \\
\text { of View }\end{array}$ & & $\begin{array}{l}\text { - No tangible Social } \\
\text { media resources } \\
\text { - No strategy } \\
\text { - Dependance to the } \\
\text { social media provider } \\
\text { - Demand of } 24 / 7\end{array}$ \\
\hline
\end{tabular}


Table-2: Chances and Risks of Social Media Marketing

\begin{tabular}{|c|c|c|}
\hline & & $\begin{array}{l}\text { availability } \\
\text { - Negative feedback is } \\
\text { out of control }\end{array}$ \\
\hline $\begin{array}{l}\text { Optim al Design } \\
\text { of Consumer } \\
\text { Relationship }\end{array}$ & $\begin{array}{l}\text { + Reachable Consumer } \\
+ \text { Active involvement in Social } \\
\text { Media } \\
\text { + Balance between Social } \\
\text { Media marketing and Direct } \\
\text { Marketing }\end{array}$ & $\begin{array}{l}\text { - Social media is seen } \\
\text { merely as a tool -> } \\
\text { Consumers feel they } \\
\text { are not taken } \\
\text { seriously. }\end{array}$ \\
\hline
\end{tabular}

\section{Implementations}

The following are the conceptual and practical implementations of social media. Afterwards, we are going to present the conclusion. Dealing with a relatively new phenomenon such as social media offers a large experiment room. Although some studies have already been carried out, but there is always new things to discover, as social media continues to grow every day. From an economic perspective, the findings of this study are interesting for the following reasons. Firstly, the question of how the marketing communications for products in one platform can be performed, which relies on the commitment of the users [14].

The emotional factor plays a big role in how customers post on the Facebook wall or retweet an announcement about a book on Twitter. It shows how much time, effort and feelings that consumers invested in part in the platforms. With this situation, the companies / business perpetrators have great opportunities to gain insights into consumer behavior at relatively little cost. Only by observing their social media platforms.

Through a focused and motivated conscious customer care activities, companies can gain advantages by eWOM (Electronic Word of Mouth) from Internet users. Praise for a company, a product or a service is contagious in a good way, which spreads easily throughout social media. For businesses, it has never been so easy and cheap to obtain support for their products and services as what happens in today's highly networked social media age. However, the study about motives and needs of these promoters is still not enough. The studies in social media are still relatively young; therefore, there have not been many literatures specifically talk about motives. It shows that further research is needed to obtain more information.

Generally can be derived from the present study to draw conclusions from how business actors in book business operate on Social Media Marketing and thereby identify successful campaigns. As we have discussed before, we can classify the business actors into three parts: authors / writers, publishers, and book stores / online book stores (Amazon). The business activities may differ based on the motivations on each party.

As the brain = which produced the book, an author may use social media to maintain his virtual existence by building image toward the readers. For example, Paulo Coelho, a Brazillian novelist whose works are intended to be inspirational, always post meaningful quotes or videos on his Facebook page and Twitter account. This activity is useful in filling the time gap when he does not have information about his book release date, so his readers can still interact with him in daily basis. For publishers, the readers can use social media platforms to view the upcoming products. However, creativity is still needed so the readers can still be attached with their brands. For example, the use of book trailers in promoting a book in a more attractive way. Book stores activities in social media may be the one that have the lowest involvement and attachment toward the readers. So far, book stores only use social media platforms as advertising tools, instead of two-way communications with the readers.

Furthermore, companies can gain a lot of knowledge about their competitors and their possible strategic moves by follow their activities in social media. Be it product development, studies in test markets or designated personnels that are in demand. All of this information provides a comprehensive picture of the business competition.

\section{CONCLUSION}

The success of social media marketing activities are determined by how much the companies use specific content and how well they are received by customers / fans / users. One condition must be added that the companies have different starting conditions: some are already longer on Facebook / Twitter, already have a bigger fan base, or simply all 
have better financial and human resources, as well as values that influence their presence on Facebook. Companies can direct communications in the social media era to their advantage by publishing active posts, ask for specific content such as product development, from which the company can not only gain insight, but also sometimes they can even re-publish (repost) relevant information.

However, social media marketing can also sometimes become boomerang to companies if they are exposed to bad feedback from the consumers. Social media offers consumers a great platform to communicate their dissatisfaction with certain products and services, to the public (for example, through blogs) or to existing contacts (through a social network such as Facebook). This will be out of control of the companies, and there is nothing they can do besides taking the negative feedbacks as reflections to perform better in the future. That is why good management of social media is required.

\section{REFERENCES}

1. Willingham, Daniel. (2012). Is the Internet Killing Books? Available: http://www.danielwillingham.com/1/category/reading/1.html. Accessed December 2019.

2. Bryan, I. (2004). Community-oriented marketing: The definitive guide to enlightened business development. iUniverse.

3. Natyari, S. G., \& Pradana, M. (2016). Determinants Forming Uber Consumers' Preferences in Bandung City, Indonesia. Safety, 10(6), 7.

4. Kaplan, A. M., \& Haenlein, M. (2010). Users of the world, unite! The challenges and opportunities of Social Media. Business horizons, 53(1), 59-68.

5. Qualman, E. (2012). Socialnomics: How social media transforms the way we live and do business. John Wiley \& Sons.

6. Hoffman, D. L., \& Fodor, M. (2010). Can you measure the ROI of your social media marketing?. MIT Sloan Management Review, 52(1), 41.

7. Nelson, M. (2006). The Blog Phenomenon and the Book Publishing Industry. Publishing Research Quarterly, 22(2).

8. Boyd, D. M., \& Ellison, N. B. (2007). Social network sites: Definition, history, and scholarship. Journal of computer- mediated Communication, 13(1), 210-230.

9. Kaplan, A. M., Haenlein, M. (2011). "Two hearts in three-quarter time: How to waltz the social media/viral marketing dance", Business Horizons, 54(3), 253-263.

10. Homburg, C.h., Kuester, S., Krohmer, H. (2009). Marketing management: a contemporary perspective, London, McGraw-Hill Education.

11. Kozinets, R. V., De Valck, K., Wojnicki, A. C., \& Wilner, S. J. (2010). Networked narratives: Understanding wordof-mouth marketing in online communities. Journal of marketing, 74(2), 71-89.

12. Hennig-Thurau, T., Gwinner, K. P., Walsh, G., \& Gremler, D. D. (2004). Electronic word-of-mouth via consumeropinion platforms: what motivates consumers to articulate themselves on the internet?. Journal of interactive marketing, 18(1), 38-52.

13. Gillette, F. (2012). It's Getting Tougher to Bully Brands, In Bloomsberg BusinessWeek, August 6 - August, 12 , S. 20-22.

14. Fadillah, F., Rubiyanti, N., \& Pradana, M. (2015). Pengaruh Perilaku Konsumen Terhadap Keputusan Pembelian Jasa Rekening Bersama (Rekber) Blackpanda Sebagai Sarana Pembayaran Yang Aman.

15. Cavazza, F. (2008). Social Media Landscape, Available: http://www.fredcavazza.net/2008/06/09/social-medialandscape/. Accessed: June 9th, 2008. 